\title{
The Struve Geodetic Arc: the development of the triangulation, technical possibilities, and the initiation of the project
}

\author{
Ruta Puziene \\ Department of Geodesy and Cadastre, Vilnius Gediminas Technical University, Vilnius, 10223, Lithuania \\ Correspondence: Ruta Puziene (ruta.puziene@vgtu.lt)
}

Received: 8 July 2019 - Accepted: 17 September 2019 - Published: 25 October 2019

\begin{abstract}
The determination of parameters of the Earth's ellipsoid is quite a difficult task that gives no rest to scientists to this day. One of the more famous works is the Struve Geodetic Arc, which was stretched from the Black Sea to the Arctic Ocean by employing the method of a triangulation network and which is included in the UNESCO World Heritage Site list. However, until this project was implemented, many steps of scientific and technological advancement had to be taken, the entirety of which created the conditions for the realization of this project. A study of the method of triangulation measurements, the development of geodetic devices, the state politics of the Russian Empire in the 17th-19th centuries in the field of geodesy, and the development of triangulation during this period are presented in the article. Moreover, a study of the origins of the Struve Geodetic Arc project that led to such a grand result is conducted. The obtained results reveal that certain factors predetermined the favourable conditions for the successful execution of the project of this geodetic arc.
\end{abstract}

\section{Introduction}

The triangulation method designed for the coordination of location points, which was used before the GNSS technologies took over, has become a thing of the past. There is logic to it: the technologies have changed, and the nature of the work being conducted is disappearing. During their time, triangulation networks were a main geodetic method for the coordination of points and the mapping of a territory. Important work was carried out in both the field of cartography and geodetic science. Measurements of a triangulation network have greatly contributed to both the cartography field and the science of the Earth's form. During the compilation of a geodetic triangulation field from obtained measurement results, the parameters of the Earth's ellipsoid were being determined. One of the most famous scientific projects that required international cooperation, and which was conducted with the employment of triangulation, was the Struve Geodetic Arc, included in the UNESCO World Heritage Site list in 2005.

The Struve Geodetic Arc connects the Black Sea with the Arctic Ocean. This chain of a triangulation network is stretched across 10 current states, and its length is $2880 \mathrm{~km}$. The triangulation network consists of 258 triangles and 265 geodetic points; coordinates of 13 points were determined by employing astronomical methods, and measurements were taken in the territory between the Black Sea and the Arctic Ocean with the cooperation of scientists from two states. Astronomical and geodetic operations continued for more than 40 years, and it took several years to publish coherent and systematically presented material (Struve, 1861a). The Struve Geodetic Arc was an enormous scientific project implemented in practice, which would prove to be a challenge even for modern specialists.

When, by the initiative of the Russian Empire, the establishment and measurements of extensive triangulation networks aimed at mapping the territory were launched in the 19th century in the empire, there were no plans for the Struve Geodetic Arc and its measurements. What are the origins of and the factors conditioning the initiative of such a scale, requiring both enormous financial resources and diplomatic skills and the international cooperation between the Russian Empire and the United Kingdoms of Sweden and Norway? Why did the geodetic establishment and measurements only 
speed up in 19th century and had not been performed on a large scale earlier?

Looking at the past, several factors related to scientific development and practical needs can be distinguished; only in the 19th century were the order and interaction of these factors able to condition the possibility of the establishment of a geodetic basis as well as the birth and implementation of the Struve Geodetic Arc project.

\subsection{Invention of a triangulation network}

In the 16th century, Gemma Frisius was the first to describe the principles of a triangulation network (Skempton and Brown, 1973). The scientist offered theoretical rudiments of a triangulation network, whose practical implementation was halted due to the contemporary state of technologies, the absence of devices for precise measurements of angles, and the lack of private and state interest.

The invention of Gemma Frisius was developed and employed in practice in the second half of the 16th century by Tycho Brahe, who performed the measurements of triangles and published the first map of the northern European region; during the compilation of this map, a geodetic plan was used (Haasbroek, 1968; Bennett, 1991; Skempton and Brown, 1973). In the beginning of 17th century, the works of Willebrord Snel van Royen, who personally knew Brahe, laid down the basis for the current usage of a triangulation network. He measured the triangulation network, consisting of 33 triangles, and determined the coordinates of the points (Skempton and Brown, 1973; Villar-Cano et al., 2019). Furthermore, he was the first person to measure the meridian chain for the determination of the radius of the Earth by employing a triangulation method (Brunner, 1992).

After Holland, France also became interested in the triangulation method. Jean Baptiste Colbert, the financial minister of Louis IV, thought that reliable topographic maps were required in order to realize his ambitious projects of the construction of roads and canals which would stimulate economic progress. Before the application of a geodetic basis in the creation of maps, they were very inaccurate, and the distances between objects were highly distorted. On many occasions, distances from a certain point to a city were described in riding days. In turn, a cartography project of the territory of England was initiated in 1791 (Heiser, 2001).

In the 18th century in the French academy of sciences, debates regarding the Earth's form were being carried out - for example, whether its circumference is greater when it is measured around the poles or when measuring around the Equator. In order to determine the truth, Louis VI launched two expeditions (in cooperation with Spain): to Meänmaa in Lapland, near the Arctic Circle, and to South America (the territory of the current Republic of Ecuador) at the Equator. It was one of the first geodetic missions carried out in accordance with modern scientific principles and the first expedition on such a large scale and on the international scientific level. Measurements made during the expeditions provided the first precise determination of the Earth's form (Ferreiro, 2013).

Gradually, with the improvement of measuring tools and the development of technologies and the appearance of state interest, state territories were first mapped with the usage of the method of geodetic network triangulation.

\subsection{Technological evolution of angle-measuring devices}

Gemma Frisius offered a prototype of an angle-measuring device in 16th century, whose operation principle is similar to one of a theodolite. He describes this device, consisting of a disc divided into four quarters. In accordance with his recommendations, each quarter should have been divided into $90^{\circ}$. The end of a "viewing ruler" was fastened to the centre of the disc. The other end with a viewing device may have been lifted across the disc. The methodology of measurement by the device is also described and recommendations are provided (Skempton and Brown, 1973). During the times when Gemma Frisius lived, angles were measured by a cross-staff, goniometer, and astrolabe; therefore, a proposal to use a full circle for measuring angles was fairly innovative.

A basic angle-measuring device was created when a binocular, microscope, vernier, level, and cross hairs were inserted into the goniometric device. Étienne Lenoir invented the first repeating circle, which was a precise angle-measurement device in those times. In around 1784, he, with his assistant Jean-Charles de Borda, improved this device (Smeaton, 2000).

Great geodetic theodolites, invented in 1787 in accordance with an order placed by Great Britain, namely the Ramsden theodolites (great geodetic theodolites were created by Jesse Ramsden), were a real masterpiece of those times (Martin and McConnell, 2008; McConnell, 2013, 2016). This invention made the theodolite a current precise geodetic anglemeasurement device (Avram et al., 2016). In 1783, after the topographic plans started in Great Britain, the demand for geodetic, astronomical devices increased. The demand was so high that Jesse Ramsden launched a big business. He developed a circular dividing engine, which allowed him to divide the arcs of sextants, theodolites, and protractors faster and with a greater accuracy than hitherto. Moreover, he implemented many different improvements in devices he was inventing. His work was known throughout Europe. In 1788, he started proving to his clients that circular instruments are much more suitable for measurements than quadrants (McConnell, 2013, 2016).

Edward Troughton (Skempton and Brown, 1973; Chapman, 1983) is the second famous inventor in Great Britain who contributed to the improvement of these devices. He constructed a $2 \mathrm{ft}(0.6096 \mathrm{~m})$ transit theodolite (the first in history) and manufactured theodolites, repeating circles, etc. Furthermore, he, similarly to Jesse Ramsden, provided de- 
vices for cartography being performed in Great Britain, constantly improving the devices (Skempton and Brown, 1973).

In around 1800, the production concept of devices changed, from "the bigger, the better" to "the more precise, the better". This concept was first implemented in the workshops of German and French craftsmen (McConnell, 2016). Famous craftsmen of devices for triangulation measurements of those times are Wilhelm Gottlob Benjamin Baumann and Georg von Reichenbach (Struve, 1861a), who were improving geodetic devices and opening up opportunities for geodetic work and whose devices, together with devices of other craftsmen, were used in order to take measurements of the Struve Geodetic Arc.

\subsection{State interests}

For designing engineering devices, the development of the trade with further regions, military purposes, etc., fairly precise topographic maps compiled on the geodetic basis are required. Only having coordinated points allows the precise mapping of a territory to exist and the actual location of a place to correspond to that in a map. After the comparison of maps compiled before and after the triangulation network measurements and the accuracy of locations mapped based on geodetic measurement, clear differences can be seen. Distances between objects correspond to the reality, and rivers and roads are of a proper length and properly located in relation to each other, which was not the case during the pregeodetic period.

After the description of the triangulation network method, scientists started isolated experimental network measurements and compiling precise maps on the basis of a geodetic network. After this became possible, practical benefits on a state level were discovered, and extensive work on the establishment and measurements of triangulation networks and territory mapping were initiated. After Holland, France, Great Britain, the Russian Empire, and other states became interested in opportunities offered by a triangulation network. Then, territories of countries began to be mapped on the basis of triangulation network measurements. As a result, the development of triangulation networks on the state level created favourable conditions for the creation of the Struve Geodetic Arc.

\section{Development of geodetic and cartographic works in 18th-19th centuries in the Russian Empire}

Triangulation demands an energetic leader with excellent scientific knowledge (Borre, 2014). This combination is not found very often. Moreover, this work requires sufficient financial resources and the interest of state leaders. In this section, the interaction of these factors during the development of triangulation measurements in the Russian Empire will be discussed. It will be revealed that the lack of any one of these components in that time significantly slowed down the ad- vancement of this work. And only after a certain level was reached did wide-scale geodetic works of a required precision, which allowed implementing the technical part of the idea of the Struve Geodetic Arc, become possible.

In the 18th century, after Peter I came into power, the state territory of the Russian Empire was first mapped, and the required specialists started to be prepared with the aid of the state. The academy of sciences in Saint Petersburg, established in 1724, received a task in 1726 to compile an atlas of the Russian Empire. There, an issue arose in that there was no geodetic basis established in the country which would have helped in precisely coordinating the location. A French astronomer and cartographer, Joseph Nicolas Delisle, invited to Russia by Peter I, recommended establishing geodetic networks within the country territory; however, due to various reasons, this was an impossible task at that time, and the atlas of the territory of the Russian Empire was compiled with no regard for these recommendations (http://expositions.nlr. ru/ex_map/atlas_1745/, last access: 18 June 2019). However, the idea and the need to create a geodetic network on the state territory for its precise mapping were voiced, and individual initiatives were carried out.

The establishment of geodetic networks on the state level only essentially began in the 19th century. The director of the military topographical department, lieutenant general Fiodor Frydrich Teodor Shubert, wrote in a report of this department (Shubert, 1837) that, although geodetic works were first performed under the command of the general staff from the moment of its establishment, at that time, they were inferior and insignificant. Although after the reorganization of this agency that took place on 30 January 1772, an opportunity for starting to create maps and plans was created; there no significant progress was made. During the reorganization of the general staff in 1796, His Imperial Majesty's Drawing Office was established, and it was reshaped into the imperial Depo-Kart (imperial Map Department) in 1797. As already mentioned, before that, geodetic measurements, namely the compilation of topographic plans and maps, was assigned to the general staff, and the Geography Department (established in 1735) was also responsible for the compilation of maps and their engravings (Kolchinskij et al., 2004). During the transfer of the existing materials to the Map Department, only a few old insignificant drafts and no fully finished maps were given. Shubert (1837) states that, due to poor remaining materials on the competencies of specialists, nothing specifically can be said; however, what can be stated is that due to imperfect methods and the fact that it still was a newly developing field in both the Russian Empire and other European countries, as well as due to the prevailing confusion in this field, the work performed during that time was not yet significant from a scientific perspective. Coordinates of some cities were determined by astronomical methods, and the measurement of triangles of triangulation networks was attempted; however, it was not a directed systematic operation resulting in precise and proper outcomes. 
In 1797, the newly created Depo-Kart department had to play a role not only in the creation of maps but also in their archiving. An order was also issued that any map or a plan to be published had to be approved by this institution. The importance of maps' precision was understood on the state level, and this was revealed when they tried to avoid the distribution of unapproved cartographic materials created by unqualified amateurs.

In 1800, the aforementioned Geography Department was merged with the Depo-Kart. In 1797, the topographic work of the Lithuanian Governorate (later Vilnius and Grodno governorates) was finished, and that of the Russian-Finnish part (later the Vyborg Governorate) and the Estonian Governorate was finished in 1798. Fiodor Frydrich Teodor Shubert stated (Shubert, 1837) that although, from the positions of the 19th century, these works would have been considered to be of poor quality, it was the start of the precise and systematic cartography of the territory of the Russian Empire.

More significant changes in the beginning of the 19th century in the field of geodesy and cartography started on 31 July 1801. Petr Kornilovich fon Suchtelen, who was greatly trusted by both the state and His Imperial Majesty, was appointed as a general engineer, the leader of the Map Department. Suchtelen acknowledged that the first and most important goal in the field of geodesy in order to have a proper cartographic material is to have main geodetic points with known coordinates (Shubert, 1837). For that purpose, geodetic networks needed to be established, and their precise measurements needed to be carried out.

During 8 years of Petr Kornilovich fon Suchtelen's leadership, rather important continuous changes were made (Shubert, 1837). As early as the first year, the elevation of the status of the employees of the Map Department was obtained from the emperor. Geodetic plans of strategically most important, in the leader's opinion, locations were taken care of. These are the locations beyond the Neva River between the Gulf of Finland and Lake Ladoga to the Vyborg Governorate, the Estonian coastline from the mouth of the Narva River to the Livonia borders, and a part of the Volhynian Governorate bordering Austria. Also, a lot of attention was dedicated to the cartographic materials being created abroad. In order for the department to be supplied yearly with the newest maps published abroad, in 1802, an order was issued to provide 1000 chervonets for their purchase. This order allowed a rich collection of the newest maps, plans, and memoirs to be accumulated.

In order to coordinate points and create geodetic networks, the department needed competent specialists with the ability to perform work of proper quality. In 1802, certain officers were appointed for astronomy studies by the academician Fiodor Frydrich Teodor Shubert. First officers sent to study were Colonel Dovre; Major Fridericy; Captain Neidgart; and Poruchik Tesliav, Garting, Karl Tenner, and Ivanov. The training took 2 years and was finished in 1804 (Shubert, 1837).
As can be seen, Karl Tenner, who measured $48.4 \%$ triangulation triangles of the Struve Geodetic Arc (Struve measured $38.8 \%$, Christopher Hansteen measured $4.7 \%$, and Nils Haqvin Selander measured $8.1 \%$ ) and who, along with Struve, had the idea of a geodetic arc for scientific purposes, is included in the list.

Petr Kornilovich fon Suchtelen's achievement is that he understood the importance of the coordinated points, and in accordance with his instructions, the department's employees received training and acquired the necessary knowledge and skills for the further establishment of triangulation networks as well as for the measurements of the Struve Geodetic Arc.

After the change of the leader of the department, no new activities were conducted (Shubert, 1837).

During the performance of cartography of the territory of the Russian Empire, including edges of neighbouring states, a map of Russia was compiled in 1814, which was later named the 100-page map. One of the greatest achievements of Suchtelen is that he was the first to notice an important deficiency of the 100-page map: there were no reliable points that could have been used to connect the map with a location. That was due to the fact that there were no established geodetic networks with coordinated points. Without a geodetic network, he understood the necessity to initially have at least a few points whose coordinates would be determined astronomically. In this manner, gradually, the necessity of the establishment of a triangulation network in the territory of the empire revealed itself.

The establishment and measurement of triangulation networks in the Russian Empire sped up in the first half of the 19th century, after the war with Napoleon in 1812, which halted geodetic initiatives because officers were participating in military actions, and, at that time, there were still no properly trained civilian specialists. After the war and the initiation of intensive surveying works of the territory of the empire, establishment and measurement of triangulation networks were intensively performed.

On 28 February 1812, the department was renamed the military topographic department and included in the structure of the Ministry of War, which fell under the jurisdiction of the Minister of War. The department was divided into five divisions, one of which was responsible for astronomical monitoring and trigonometric plans, required for the mapping of large areas. Officers who worked in the military topographic department received a salary in addition to the salaries they received from the service they were performing as officers (Shubert, 1837), which demonstrates how important and significant this initiative was considered to be on the state level.

The time period when the military topographical department was under the jurisdiction of the Ministry of War was also beneficial due to the fact that brand-new modern devices were received, and the department was reorganized and divided into divisions in accordance with the works being performed. Due to the fact that during that time there still were no officials who belonged only to the department and were 
not simultaneously in the military, during the Napoleonic Wars, the creation of new geodetic networks, maps, and plans was almost stopped. However, regardless of difficulties that arose, some work was performed during that time, including an experimental triangulation network stretched by Tenner and Poruchik Ivanov around the Gulf of Finland between Saint Petersburg and the cities of Reval (Tallinn) and Derpt (Tartu). As could be seen, at that time, Tenner was already accumulating knowledge in the field of triangulation and, when measuring the Struve Geodetic Arc, was not a novice.

In May 1816, in accordance with the order issued by the tsar Alexander I, the department, during the reorganization of the entire army structure and subordination, was transferred from under the jurisdiction of the Minister of War into the structure of His Imperial Majesty general staff. Hereby, the department fell under the leadership of the duke, Piotr Michalovich Volkonsky, the commander of the general staff (Shubert, 1837). Increasingly greater attention was being paid to geodetic work.

Geodetic instruments were transferred to the mechanical workshop; also, an order was issued allowing officers who were sent on a mission to perform geodetic, cartographic work of state importance to be paid a daily allowance of 1-2 rubles during these missions, depending on their rank, which was not a small amount during those times. This was done in order to improve the living conditions of the employees during the missions, which reveals that the works of geodetic networks and the mapping of a territory were considered to be important enough on the state level.

In June 1821, the mechanical workshop was renamed, and it was entrusted with, apart from other work, the production of "mathematical, optical, and physical devices". Moreover, it was necessary to prepare a few students who would participate in geodetic work and repair small failures of devices on-site, therefore enhancing the maintenance of geodetic work. General Major Fiodor Frydrich Teodor Shubert was appointed as a director of the topographic division (Shubert, 1837).

The aforementioned changes allowed increasing the number of specialists, acquiring a sufficient number of measuring devices of proper quality; a separate division for the maintenance of devices was established as well as a fund for both technical issues and the benefits for employees. As a result, this state agency became competent in performing works related to the establishment of geodetic networks and measurements throughout the entire territory of the Russian Empire for both state and private interests.

The preparation of human resources was being performed systematically and according to a plan, with the coordination of their preparation process. Officials of lower ranks, named topographers, after being assigned as officers, had to demonstrate good knowledge of general sciences and great knowledge of mathematics, the creation of topographic and trigonometric plans, and the drawing of plans and their engravings. In accordance with their knowledge and skills, they were divided into two classes. A special school was established in Saint Petersburg for the preparation of specialists; students had to pass strict exams.

These actions were directed at preparing a proper number of specialists with high qualifications for cartography in the Russian Empire and refusing, if necessary, the services of the officers from the general staff in order for them to be allowed to perform their direct responsibilities. Specialists who were not officers were trained to establish geodetic networks and map a territory and were able to directly perform their responsibilities without halting their performance due to duties related to their military service (Shubert, 1837).

As can be seen, from the 18th to the 19th century, the state agency department Depo-Kart performed the establishment of triangulation networks, measurements and territory mapping grew and were strengthened, good funding was provided, and the required amount of highly qualified specialists able to perform high-quality geodetic work who later contributed to the Struve Geodetic Arc were prepared. Without the proper attention of the government, technical facilities, well-prepared specialists, and motivated leaders, it would not have been possible.

\section{The birth of the idea and initiation of the Struve Geodetic Arc}

It cannot be stated that the Struve Geodetic Arc is the first and only attempt to measure a geodetic arc for the determination of the Earth's form in the Russian Empire. The idea of measuring a geodetic arc in the western part of the Russian Empire for the determination of the Earth's form originated in the first half of the 18th century from an astronomer of the academy, Joseph Nicolas Delisle, invited by Peter I. This idea was expressed on 21 January 1737 during a meeting of the academy. In 1737, after the empress Anna Ivanovna approved the project, Joseph Nicolas Delisle started the measurements by measuring a $14.4 \mathrm{~km}$ basic line between the Danube Island and Petergof. In 1739, several triangles were measured. This is where the work ended (Struve, 1861a). There was no continuity and no compiled report, and this fragmented work had not affected the course and development of geodetic measurements.

Friedrich Georg Wilhelm von Struve states (Struve, 1861a) that, in the 19th century, Bernhard August von Lindenau, a little later than Struve himself, had the idea to measure a geodetic arc. In 1814, he wanted to measure a geodetic arc on the coast of the White Sea in order to determine the inaccuracies of the measurement results obtained in 1738 and 1805 by different measurers. The project was approved, but, due to the inability to agree on certain technical issues, it was not attempted. V. Struve learned about this project in 1820 from B. A. von Lindenau himself, when they met during a Struve's work trip as he was travelling to Munich through Gotha (Struve, 1861a). 
It is evident that before the project of the Struve Geodetic Arc, similar ideas were already being raised for the implementation of projects; however, none of them were fully implemented. When talking about the Struve Geodetic Arc, the majority of people imagine it to be an ordinary project with the ordinary sequence of events characteristic of projects. Most frequently, the need for an idea arises, an idea is born, a project itself is prepared, funding is provided, and the project's stages are implemented. However, in this case, everything was a little different. Firstly, as seen form the section above, after the human and technical resources were accumulated and the funding was provided by the state, triangulation networks started to be systematically and intentionally established throughout the Russian Empire. During the performance of these initiatives, after measuring a part of the network located in the European part of the empire, a geodetic arc from the Black Sea to the Arctic Ocean was first knowingly measured, the results of which were planned to be employed for scientific purposes.

Measurements of the Struve Geodetic Arc were firstly performed in Vilnius and Baltic Sea governorates; however, historical sources reveal that measurements dedicated only to this project at that time were not yet initiated. The main goal of the initiative was to cover territories of these governorates by a triangulation network with the intention to map them.

A triangulation network was being established and measured in the Vilnius Governorate for the purposes of mapping its territory (Shubert, 1837; Struve, 1861a). Karl Tenner had the idea to later use a part of the triangles of this network for the Struve Geodetic Arc.

Struve performed cartographic works of the territory in the Baltic Sea governorates, and it was here where an idea arose to measure a small geodetic arc.

Independently of one another, K. Tenner and F. G. W. von Struve provided different representatives with ideas regarding the measurements of geodetic arcs in those territories. Upon receiving the funding, two geodetic arcs, which later started the Struve Geodetic Arc, were measured.

According to the performance order of technological geodetic work, the measurements of the Struve Geodetic Arc (Struve, 1861a) can be divided into stages, provided in the Table 1.

Struve himself (Struve, 1861a) distinguishes several stages of the preparation of a geodetic arc.

Period I includes the time period between the birth of the idea to 1831, when Tenner and Struve measured the Lithuanian and Baltic parts of the arc, which form $81^{\circ} 02^{\prime}$.

Period II, 1830-1844, covers the measurements of the arc to the north up to the city of Tornio in modern Finland (northern latitude) and the preparation for the measurements to the south of the Dniester River.

Period III, 1844-1851, covers the measurements to the south of the Danube River and measurements in Scandinavia up to the Arctic Sea.
Period IV covers all additional works performed after 1851 , e.g. those connecting separate segments of the geodetic arc into one geodetic arc and the determination of the Earth's ellipsoid in accordance with the data of the geodetic arc (Struve, 1861a).

During the measurements, under the supervision of these specialists, the following was measured (Table 2).

Struve states (Struve, 1861a) that both he and Tenner came up with the idea regarding the measurements of geodetic arcs independently of one another. Measurements of arcs in the Vilnius and Baltic Sea governorates had already been performed when Struve and Tenner met and started cooperating; this cooperation gradually developed into a unique project.

In 1812, while a student at the University of Derpt (Tartu), Struve noticed (Struve, 1861) that the meridian that went through the university crosses locations from the Danube to Lapland, which do not rise much above the sea level and are very favourable for geodetic measurements if the chain of a triangulation network was possible to establish. Understanding the necessity of mapping the territory of Livonia, as well as wishing to consider a possibility to establish a meridian arc, he, at his own expense, organized a trip to locations of the governorate. He measured a few lines and triangles between objects that stood out in the location by using Troughton's sextant and wooden rods. Although the trip was cancelled due to the war, he confirmed that it was possible to stretch a chain of triangulation triangles through the territory of the governorate. While executing other works, he did not forget this idea, and an opportunity appeared when the Economic Union of Livonia asked him to compile an astronomical-topographic plan; he worked from 1816 to 1818 with a Troughton sextant with a $25.4 \mathrm{~cm}$ radius. The results of the triangulation of Livonia did not have the required precision but still served him in a way: it allowed him to explore the territory, and the locations for the points for the establishment of a geodetic arc between Estonia and the Dvina River were planned. In 1817, he made an offer to the Economic Union of Livonia to remeasure some of the triangles of the triangulation network with a repeating Brauman circle and to use this device to determine the latitudes of the final points of triangles of the chain of the triangulation network. However, Struve himself refused this offer, as he explained in his notes, after realizing that the aforementioned device, regardless of how great it was during the time of its purchase in 1809 , it was not as innovative and high quality (Struve, 1861a) as geodetic devices produced with the improvements made by Georg von Reichenbach.

After the cartographic project of the territory of Livonia ordered by the Economic Union, Struve (Struve, 1861a), in 1819 , presented the idea to use certain points, established near the Derptsk meridian of the already-compiled triangulation network for scientific purposes, for the measurement of a geodetic $3^{\circ} 35^{\prime}$ arc (between the island of Gogland and Jakobstad in Finland). The project was approved, and the funding for the purchase of instruments was provided by emperor 
Table 1. Stages of measurements of the Struve Geodetic Arc.

\begin{tabular}{|c|c|c|c|c|c|c|}
\hline \multirow[t]{2}{*}{ No. } & \multirow[t]{2}{*}{ Names of geodetic arcs } & \multicolumn{2}{|c|}{ Latitudes } & \multirow{2}{*}{$\begin{array}{l}\text { Supervisors of the measure- } \\
\text { ments }\end{array}$} & \multicolumn{2}{|c|}{ Measurements } \\
\hline & & from & to & & from & to \\
\hline 1 & Arc of Lithuania & $52^{\circ} 03^{\prime}$ & $56^{\circ} 30^{\prime}$ & Karl Tenner & 1816 & 1828 \\
\hline 2 & Arc of Ostzeja ${ }^{a}$ & $56^{\circ} 30^{\prime}$ & $60^{\circ} 05^{\prime}$ & Wilhelm Struve & $1816^{\mathrm{b}}$ & 1831 \\
\hline 3 & Arc of Finland & $60^{\circ} 05^{\prime}$ & $65^{\circ} 50^{\prime}$ & Wilhelm Struve & 1830 & 1851 \\
\hline 4 & Arc of Podil and Valyn & $48^{\circ} 45^{\prime}$ & $52^{\circ} 03^{\prime}$ & Karl Tenner & 1835 & 1840 \\
\hline 5 & Arc of Bessarabia & $45^{\circ} 20^{\prime}$ & $48^{\circ} 45^{\prime}$ & Karl Tenner & 1844 & 1852 \\
\hline 6 & Arc of Finmarketsk & $68^{\circ} 54^{\prime}$ & $70^{\circ} 40^{\prime}$ & Christopher Hansteen & 1845 & 1850 \\
\hline 7 & Arc of Lapland & $65^{\circ} 50^{\prime}$ & $68^{\circ} 54^{\prime}$ & Nils Haqvin Selander & 1845 & 1852 \\
\hline
\end{tabular}

${ }^{a}$ The Baltic Sea region is a territory located at the borders of the Russian Empire (18th-19th century), which consisted of governorates of Estonia, Vidzeme, and Courland.

a 1816 is indicated by Struve himself, although, at that time, the territory was measured by devices which were not characteristic of proper precision, and those measurements were not included in a geodetic arc. Here, V. Struve had the preparation of territory exploration in mind.

Table 2. Measurements of segments of the Struve Geodetic Arc.

\begin{tabular}{lrrllll}
\hline \multirow{2}{*}{ Supervisor } & \multicolumn{2}{c}{ Measured } & \multirow{2}{*}{$\begin{array}{l}\text { Lengths of arc segments } \\
\text { measured }\end{array}$} & \multicolumn{2}{c}{ Latitudes } \\
\cline { 2 - 3 } \cline { 5 - 6 } & Triangles & Base lines & & from & to \\
\hline Karl Tenner & 125 & 5 & $11^{\circ} 10^{\prime}$ & & $45^{\circ} 20^{\prime}$ & $56^{\circ} 30^{\prime}$ \\
Wilhelm Struve & 100 & 3 & $9^{\circ} 38^{\prime}$ & & $56^{\circ} 30^{\prime}$ & $66^{\circ} 08^{\prime}$ \\
Christopher Hansteen & 12 & 1 & $1^{\circ} 46^{\prime}$ & & $68^{\circ} 54^{\prime}$ & $70^{\circ} 40^{\prime}$ \\
Nils Haqvin Selander & 21 & 1 & $3^{\circ} 13^{\prime}$ & & $65^{\circ} 50^{\prime}$ & $69^{\circ} 03^{\prime}$ \\
\hline
\end{tabular}

Alexander I in Munich. Working missions of the measurers were financed by the university. During the execution of measurements, Struve (1861a, b) received the help of a navy lieutenant, baron Vasilij von Vrangel. Measurements were taken by employing a newly acquired universal Reichenbach device, astronomical theodolite, and a vertical circle with an 18 -inch radius. Geodetic surveying was performed in 1822 1827. Latitudes of the geodetic points located in Jakobstad and the island of Goglang were determined astronomically. The measurements were executed with the participation of a former Mitau (Jelgava) professor, Pauker. He performed the measurements with a vertical 18-inch Ertel circle. In 1831, all measurement and calculation work was finished. This way, one comparatively small geodetic arc, which formed $14 \%$ of the whole Struve Geodetic Arc, was measured.

The second geodetic arc, which formed $17.6 \%$ of the entire arc, was measured quite quickly, approximately at the same time, without the prior coordination of actions. General Tenner was appointed as a supervisor of surveying works in the Vilnius Governorate in 1816, in the Courland Governorate in 1822, and in the Grodno and Minsk governorates in 1825 . He had the idea to use his measured triangles of a triangulation network, which were going through the Vilnius observatory, for measurements of geodetic arc. With the consent of Duke Volkonsky, the commander of the general staff, Tenner executed measurements of a chain of triangles and two basic lines between Bristen in Courland and
Bielin in the Grodno Governorate. During the measurements, Troughton and Baumann repeating circles were used. Latitudes of marginal points were determined, employing the Bessel method and a meridian instrument. The length of an arc is $4^{\circ} 32^{\prime}$. Measurements were finished in 1827 , and completely random circumstances led to Bristen, the northern Lithuanian point of the arc, measured by Tenner to be relatively close at only $32 \mathrm{~km}$ to the west of Jakobstad (Jēkabpils, Latvia), being the southern point of the Baltic arc (measured by Struve). The idea to connect these two arcs, as V. Struve wrote (Struve, 1861a), arose on its own. In January 1828 , Karl Tenner came to Derpt to discuss the merging of these arcs with V. Struve. It can be guessed from the context of the geodetic arch measurement report written by V. Struve (Struve, 1861a) that the idea to merge the arcs belonged to K. Tenner; however, V. Struve did not directly state that.

Geodetic triangle connection initiatives under the supervision of Tenner were executed by Poruchik Juozapas Chodzka. In 1828, Reichenbach's theodolite was used to measure horizontal angles in 10 geodetic points located to the north of Pandèlys. Four of them belonged to the Baltic arc. The measurement of two points of common triangles was aimed at the performance control. Moreover, during the determination of the length of five sides of these triangles, this was done twice during the determination of their length in accordance with their basic lines, located 335 versts $(357.378 \mathrm{~km})$ from one another (straight distance). The ba- 
sic lines were from Pandèlys, located 85 versts $(90.678 \mathrm{~km})$ to the south, to Smolensk, located 250 versts $(266.7 \mathrm{~km})$ to the north. In order for the results not to be affected by other interests, calculations were carried out separately by Tenner and Struve. For the discussion and an assessment of the obtained results of the executed works, General Shubert, the director of the military topographic department, and a scientist, Friedrich Wilhelm Bessel, who worked at the University of Königsberg, were invited. The results were sent to the evaluators in sealed envelopes: the letter by Struve was sent at the end of 1829, and the letter by Tenner was sent on 11 January 1830. The results matched (Struve, 1828, 1861a; Shubert, 1837, 1842, 1844).

This was a great outcome. As Struve stated (Struve, 1861a), these successful $8^{\circ} 25^{\prime}$ measurements of a geodetic arc between the island of Gogland and the town of Bielin inspired them in further work and became a reference point for the entire large international project, which was a a task they continued to work on for the rest of their lives. A geodetic arc stretched from the Black Sea to the Arctic Ocean. An idea had been expressed to continue this arc to the south, but it was not implemented.

\section{Conclusions}

Despite the invention of a method for the determination of coordinates of points with the usage of triangulation principles in the 16th century, it had not yet been applied on the state level. The triangulation method was first employed for cartography in the second half of the 16th century, and a few dozen triangles were measured in the first half of the 17th century. During the almost 100 years, only three scientists, who conducted a few experiments thanks to a private initiative, were interested in this method. Although there were no precise maps of the territories of states demonstrating a precise location during that time, and although with the employment of geodetic measurements, this problem could have been solved, no action was taken. This was partially due to the lack of interest from the state and partially due to the lack of technologies: there were no suitable devices designed for measuring horizontal angles.

With the improvement of technologies, as well as with the appearance of a need for precise maps of territories of a country on the state level, gradually, establishment and measurements of triangulation networks began. In the Russian Empire, after the 17th century, the importance of the cartographic mapping of a territory was first realized, and, gradually, the reorganization and the development of the institution as well as the preparation of specialists responsible for the cartographic works were being initiated; greater attention was paid to funding. This provided good opportunities for the establishment of triangulation networks in the territory of the empire and proper conditions for the implementation of the project of the Struve Geodetic Arc.
The operation of the Depo-Kart department, responsible for geodetic works, depended on the attention of the state leaders and the appointment of suitable supervisors. By the initiative of some supervisors, the operation of the department was active, and, under the supervision of others, it was virtually halted and did not result in any significant changes.

The project of the Struve Geodetic Arc was not made up before the establishment and measurement works of the entire arc. Firstly, during the execution of geodetic works, Sturve and Tenner, independently of one another, had the idea to measure geodetic arcs in the governorates of the Baltic Sea and Vilnius. Accidentally, the end point of one of them was relatively near to another arc, only $32 \mathrm{~km}$ from the initial point of the other arc. Then the idea of connecting these arcs into one was born. The successful completion of the work inspired Tenner and Struve to further develop the project of creating a geodetic arc stretching from the Black Sea to the Arctic Ocean.

This project was born gradually by executing one work after another, and it was not planned from the start. The idea was born only after a measurement of two small geodetic $\operatorname{arcs}, 3^{\circ} 35^{\prime}$ and $4^{\circ} 27^{\prime}$, which were accidentally near one another, and their successful connection into one arc. This work was executed in stages, the funding was received from different sources, and creation and implementation of this project were affected by many favourable conditions.

Data availability. Underlying research data can be found for free on the Internet: https://elib.rgo.ru/safe-view/ 123456789/218762/1/MTIxMDg2NDhfU3RydXZILCBWOLBza WxpeSBZYWtvdmxldmljaCAoMTc5My0xODY0KS4gRHVn0L AgbWVyaS5wZGY= (last access: 18 June 2019; Struve, 1861a), https://elib.rgo.ru/safe-view/123456789/ 218754/1/MTIxMDg2NDlfU3RydXZILCBW0LBzaWxpeSBZYW tvdmxldmljaCAoMTc5My0xODY0KS4gRHVn0LAgbWVyaS5 wZGY = (last access: 18 June 2019, Struve, 1861b), and https://fulltext.lib33.ru/biblioteka/b/bk/01smw/01_08tkj/b000000747/ FB/files/assets/basic-html/index.html\#1 (last access: 18 June 2019; Shubert, 1842).

Author contributions. This work is the author's own, and all sources of information have been cited.

Competing interests. The authors declare that they have no conflict of interest.

Review statement. This paper was edited by Johannes Ihde and reviewed by Andreas Reinhold and one anonymous referee. 


\section{References}

Avram, D., Bratosin, I., and Ilie, D.: Surveying theodolite between past and future, Journal of Young Scientist, IV, 129-134, 2016.

Bennett, J.: Geometry and surveying in earlyseventeenth-century England, Ann. Sci., 48, 345-354, https://doi.org/10.1080/00033799100200331, 1991.

Borre, K.: Fundamental triangulation networks in Denmark, J. Geodetic Sci., 4, 74-86, https://doi.org/10.2478/jogs-2014-0010, 2014.

Brunner, F. K.: Refraction, refractive index and dispersion: some relevant history, In the Hague, the Netherlands, Refraction of transatmospheric signals in geodesy, Proceedings of the symposium the Hague, Nederlandse commissie voor geodesie, the Netherlands, 1992.

Chapman, A.: The Accuracy of Angular Measuring Instruments Used in Astronomy Between 1500 and 1850, J. Hist. Astron., 14, 133-137, https://doi.org/10.1177/002182868301400205, 1983.

Ferreiro, L. D.: Measure of the Earth: The Enlightenment Expedition That Reshaped Our World, Basic Books, New York, 376, 2013.

Haasbroek, N. D.: Gemma Frisius, Tycho Brahe and Snellius and their triangulations, W. D. Meinema, N. V., Delft, the Netherlands, 119 p., https://doi.org/10.1007/978-4-431-669968_3, 1968 .

Heiser, W. J.: Early statistical Modeling of Latent Quantities: The History of Distance Measurement by Triangulation, New Developments in Psychometrics: Proceedings of the International Meeting of the Psychometric Society IMPS2001, Osaka, Japan, 15-19 July, https://doi.org/10.1007/978-4-431-66996-8_3, 2001.

Kolchinskij, E., Sytin, A., and Smagina, G.: Essays on the development of natural science in Russia in the XVIII century, 242 p., Nestor-History, St. Petersburg, 2004 (in Russian).

Martin, J.-P. and McConnell, A.: Joining the observatories of Paris and Greenwich, Notes and Records, 62, 355-372, https://doi.org/10.1098/rsnr.2008.0029, 2008.

McConnell, A.: Jesse Ramsden: The Craftsmann who believed that big was beautiful, The Antiquarian Astronomer, 7, 41-53, 2013.

McConnell, A.: Jesse Ramsden (1735-1800): London's Leading Scientific Instrument Maker, Ashgate Publishing, Ltd., Routledge, Aldershot, 344 p., 2016.

Shubert, F.: Notes of the Military topographical depot, at the highest level of His Imperial Majesty, commanded by the director of the Depot General-Leitenantom Shubert, I, printing house of the Expedition for the procurement of government securities, St. Petersburg, 1837 (in Russian).

Shubert, F.: Notes of the military topographical department, at the highest level of His Imperial Majesty, commanded by the director of the Department of General Shubert, VIII, 321 p., available at: https://fulltext.lib33.ru/biblioteka/b/bk/01smw/01_ 08tkj/b000000747/FB/files/assets/basic-html/index.html\#1 (last access: 18 June 2019), printing house of the Expedition for the procurement of government securities, St. Petersburg, 1842 (in Russian).
Shubert, F.: Notes of the military topographical department, at the highest level of His Imperial Majesty, commanded by the director of the Department of General Shubert, IX, 928 p., printing house of the Expedition for the procurement of government securities, St. Petersburg, 1844 (in Russian).

Skempton, A. V. and Brown, J.: John and Edward Troughton, msthematical instrument makers, Notes and Records, 27, 233-249, https://doi.org/10.1098/rsnr.1973.0018, 1973.

Smeaton, W. A.: The Foundation of the Metric System in France in the 1790s; the importance of Etiene Lenoir's platinum measuring instruments, Johnson Matthey Tech., 44, 125-134, 2000.

Struve, W.: Géodésie. Sur la jonction de deux mesures de degres executees en Russie, Bibliotheque Universelle, des Sciences, Belles-Lettres et Arts. Sciences et arts. Faisant Suite a la Biblioteque Britannique, Redigee a Geneve, XIII anee, XXXIX, 169-173 p., available at: https://play.google.com/ books/reader?id=_GkTAAAAYAAJ\&hl=lt\&pg=GBS.PA17 (last access: 18 June 2019), 1828.

Struve, W.: The arc of the meridian of $25^{\circ} 20^{\prime}$ between the Danube and the Arctic Sea, measured from 1816 to 1855 under the direction of K. Tenner, N. H. Selander, Ch. Hansteen, and W. Struve, I, 334 p., available at: https://elib.rgo.ru/safeview/123456789/218762/1/MTIxMDg2NDhfU3RydXZILCBW OLBzaWxpeSBZYWtvdmxldmlja-

CAoMTc5My0xODY0KS4gRHVn0LAgbWVyaS5wZGY= (last access: 18 June 2019), Imperial St. Petersburg Academy of Sciences, St. Petersburg, 1861a (in Russian).

Struve, W.: The arc of the meridian of $25^{\circ} 20^{\prime}$ between the Danube and the Arctic Sea, measured from 1816 to 1855 under the direction of K. Tenner, N. H. Selander, Ch. Hansteen, and W. Struve, II, 485 p., available at: https://elib.rgo.ru/safeview/123456789/218754/1/MTIxMDg2NDlfU3RydXZILCBW0L BzaWxpeSBZYWtvdmxldmlja-

CAoMTc5My0xODY0KS4gRHVn0LAgbWVyaS5wZGY= (last access: 18 June 2019), Imperial St. Petersburg Academy of Sciences, St. Petersburg, 1861b (in Russian).

Villar-Cano, M., Marques-Mateu, A., and Jimenez-Martinez, M. J.: Triangulation network of 1929-1944 of the first 1:500 urban map of València, Surv. Rev., published online, https://doi.org/10.1080/00396265.2018.1564599, 2019. 